\title{
VIRUNGA NATIONAL PARK Steder og rettigheder for gorillaer og mennesker i Afrika
}

Parc National des Virunga blev etableret i 1925 som Afrikas første nationalpark og dækker et område på $7.800 \mathrm{~km}^{2}$, der grænser op til Parc National des Volcans i Rwanda og Rwenzori Mountains National Park i Uganda. Virunga er udnævnt til UNESCO-verdensarv og er sammen med de tilliggende parker et af verdens absolut mest prestigiøse sites. Her findes endnu nogle hundrede af den udrydningstruede bjerggorilla og okapien eller skovgiraffen, som først blev opdaget af europæerne i 1901, der indtil da kun havde hørt om den zebralignende giraf som den "afrikanske enhjørning"; og her findes stadigvæk bestande af skov- og savanneelefanter, bøfler, chimpanser plus en lang række uverificerede væsner, som indtil videre hører til det kryptozoologiske felt. Stedets mangfoldighed af naturog klimatyper med de store indlandssøer, savanner, enorme skovområder, iskolde snedækkede bjergtoppe, tropiske sumpområder, vulkaner i udbrud og græsklædte sætere danner habitat både for de store pattedyr, vi forbinder med Afrikas vilde natur, for pygmæstammer og for et utal af arter, som enten tilhører zoologernes mindre kendte repertoire, de endnu uopdagede eller fabeldyrenes univers.

Da Henry M. Stanley på sin Transatlantiske Afrikaekspedition i 187477 rejste gennem området omkring Lake Victoria, beskrev han det som 
"the Pearl of Africa", et sted med ufattelige rigdomme, et lyst og eminent beboeligt sted for en mønsterværdig og forbilledlig civilisation, som han inviterede "filantropiske kapitalister" til for at drive frihandel og derved udrydde slavehandel og fjendtligheder mellem stedets forskellige indfødte stammer. Blandt andet foreslog han i et for ham typisk ekstatisk og utopisk overskridende overbud, at man kunne tænke sig en jernbane rundt i højlandet i Afrikas Lake District, som merkantilt ville forsone de stridende folkeslag og samtidig tilbyde den rejsende uendelig nydelse ved de panoramiske vistas ud over det ekstraordinært skønne landskab. Stanleys beskrivelser bekræfter en lang tradition for at tillægge området ved Virunga- og Rwenzoribjergene en dyb historisk og mytologisk mening, som står i modsætning til den udbredte forestilling om resten af Afrika som historieløs: Det er her, at Ptolemæus placerede de legendariske Månebjerge, hvorfra Nilen og dermed de antikke civilisationer har deres udspring; her mente Stanley at kunne lokalisere spor af de sagnomspundne kongedømmer, der i kristendommens tidlige historie ifølge myten skulle have etableret sig i det indre Afrika, og som Tarzan genopdager som utopiske øer af oplysning og renæssance midt i det ellers mørke Afrika. Og det er herfra mennesket som art for 2,4 millioner år siden rejste sig på bagbenene for at påbegynde sin udvandring til resten af verden skilt fra sine gorilla- og chimpanseslægtninge, der forblev i de store skove på vestsiden af The Great Rift Valley - som Karen Blixen holdt af at overflyve med sin ven Denys Finch Hatton - mens menneskearten på østsiden tilpassede sig lavlandets savanner.

Blandt victoriatidens opdagelsesrejsende var det almindeligt at placere de højst udviklede afrikanske kulturer i dette område og altså fremstille stedet som et højdepunkt i både topografisk og civilisatorisk forstand. Imidlertid er Virunga- og Rwenzoribjergene i dag blevet indtaget og erobret af de "heart-of-darkness"-fortællinger, der siden Joseph Conrads roman har hjemsøgt ikke blot det indre af Congo, hvortil romanen først henlagde sine ufattelige rædsler, men hele Congo og gennem den udbredte brug af metaforen også Afrika som helhed. Den geofysiske lokalitet for "mørkets hjerte" som retorisk figur for et sted, hvor rædslerne overgår vores fatteevne, har flyttet sig topografisk fra området omkring Stanley Pool til Kivuprovinsen og grænseegnene mod Uganda og Rwanda, hvorfra folkedrabet i 1994 udløste store flygtningestrømme ind i DR Congo og en dermed forbundet 
borgerkrig, der med få og kortvarige afbrydelser har hærget regionen siden. - En krig med mellem 5 og 10 millioner ofre, det største antal siden 2. verdenskrig, der ikke desto mindre omtales som "den glemte krig", fordi den på trods af sporadiske omtaler af spektakulær vold ikke spiller nogen rolle i den globale medievirkelighed sammenlignet med f.eks. krigene i Afghanistan eller Irak-Syrien.

Virunga- og Rwenzoriområdet har i denne periode i højeste grad været ustabilt. Som en væsentlig del af den militære strategi konkurrerer et stort antal militser med Congos regeringshær om at udføre de mest bestialske rædselsgerninger mod civile, der foruden drab lider under udbredt og systematisk "rape warfare", seksuel vold og bortførelser af civile som sexslaver eller børnesoldater. De nationale grænser angiver ikke sikre demarkationer af stater, men er overdetermineret af skiftende og tværgående alliancer, der ikke længere primært er etnisk defineret. Grænserne bestemmes derimod af de involverede militslederes eller "lensgrevers" økonomiske interesser i jordens store forekomster af diamanter, guld, uran og frem for alt coltan, et mineral, der anvendes i mobiltelefoner, og som bjergkædens vulkaner har udspyet gennem æoner, og i dag er blevet stedets forbandelse. Også nationalparkernes grænser er dermed truet: Dels indeholder de eftertragtede mineraler og er derfor under belejring af grådige militser som den berygtede M23, dels har flygtningestrømmene bragt så mange nødlidende mennesker til reservatets udkant, at presset fra krybskytter og kulsviere, der faktisk udgør den største trussel mod naturen, er stærkt stigende.

Det britiske olieselskab SOCO har gennem ulovlige koncessioner med Congos regering fundet store oliereserver under Lake Edward, som er en del af Virunga-parken, og det hidtidige mønster for ødelæggelse af landet på grund af international plyndring af dets alt for rige naturressourcer får dermed endnu en kynisk dimension: Ikke blot har denne plyndring pr. stedfortrædere afstedkommet enorme lidelser for de mennesker, der har beboet denne region; stedet forstået både som natur og som sted, dvs. ikke som commonplace, men som et fælles sted, en biologisk, antropologisk, mytologisk og historisk oprindelse for både mennesket og dets artsslægtninge, er også truet af ødelæggelse. Som en direkte konsekvens af den britiske dokumentarfilm Virunga (2014), der afslørede SOCOs lyssky forretninger 
og truslen mod nationalparkens bestand af gorillaer, indgik SOCO en aftale med WWF om ikke at udføre undersøgelser i parken, der ville kunne medføre skade på stedets unikke miljø. Som ventet af NGO'er som f.eks. Global Witness og Human Rights Watch er aftalen mellem Congo og UNESCO, der hidtil har sikret områdets status som verdensarv, imidlertid fortsat under stærkt pres. Den 14. marts 2015 kunne man læse i BBC News Africa, at Congo planlægger at revidere nationalparkens grænser, således at SOCO uhindret af naturbeskyttelseskonventioner kan udvinde olien under den særdeles sårbare Lake Edward. - Som anført af Virunga-parkens direktør risikerer udslip herfra at nå helt frem til den spanske kyst via Nilen og Middelhavet og dermed forurene ikke blot, hvad der i stigende grad opfattes som et ikke-sted i Afrika, men også vores del af verden og os selv. ${ }^{1}$

Hvis ikke det var i modstrid med den opfattelse af kontinentet, som ofte bliver illustreret med Hegels berygtede påstand om, at "Afrika ikke har nogen historie", så fortjener disse vilde bjerge mere end nogen andre steder i verden betegnelsen "et klassisk sted". Med dette mener jeg, at stedet i særlig dyb - historisk og antropologisk - forstand er mættet med betydning. Artiklens geokritik bygger imidlertid også på den opfattelse, at sådanne steder dels er diskursivt og performativt formateret og derfor også historisk foranderlige, dels at sådanne diskurser - f.eks. helt banale dyreprogrammer i TV - i kombination med geofysiske og historiske kræfter på stedet ikke kun skaber eller ødelægger lokale topografiske betingelser for liv, men også determinerer de relationer og muligheder for handling, som Europa har over for Afrika. Artiklens kritiske perspektiv angår det forhold, at vi med truslerne mod Virunga som case ikke kun står over for at tabe et værdifuldt og enestående sted i verden, hvor udryddelsen af gorillaen frem for alt fremstår som et uendeligt trist og dog desværre realistisk perspektiv, men også risikerer på længere sigt at miste både "Afrika" og en "global fornemmelse for sted" (Massey).

1 "SOCO and WWF agree way forward on future activity in Virunga National Park (DRC)" 11.6. 2014. http://www.socointernational.com/. "British oil company's backtracking on World Heritage Site looks like a ruse" 13.6 2014. http://www.globalwitness.org.library/british-oil-company. "DR Congo seeks Virunga park boundary change". BBC News Africa. http://www.bbc.com/news/world-africa. 


\section{CONGO REFORMBEVÆGELSENS RÆDSELSKAMPAGNE}

På baggrund af stadig flere rapporter fra især protestantiske missionsbevægelser om plyndringer, gidselstagninger og drab på indfødte i forbindelse med 1890'ernes intensiverede inddrivning af rågummi i Congo organiseres i 1905 en reformbevægelse med base i England. Efter en usædvanlig hård mediestrid ender kampagnen med, at Kong Leopold må overdrage Fristaten Congo til den belgiske stat i 1908. Bevægelsens ledende skikkelse, journalisten Edmund Morel, er i begyndelsen skeptisk over for rædselsrapporter, der indløber til London fra fortrinsvis protestantiske missionærer. Han forsvarer Fristaten Congo mod angrebene, men bliver senere kampagnens hovedskribent og strateg, især kendt for bestselleren Red Rubber. The Story of the Rubber Slave Trade Flourishing on the Congo in the Year of Grace 1906 fra 1906. For Morel sker der et holdningsskifte efter et møde i 1899 med Mary Kingsley, som på baggrund af to længevarende rejser i Vestafrika udformer en særlig variant af frihandelstanken, der gør indtryk på Morel. Kingsleys hovedpointe er, at kolonisatorerne bør anerkende og respektere afrikanske samfund som rationelle og effektive på deres egne betingelser i stedet for at påtvinge dem europæisk formede genopdragelsesprogrammer. Dette er en udvidelse af både frihandelsdoktrinen og den britiske formel for "indirect rule", idet den understreger, at frihandlen også gælder indfødtes ret til at handle med hvem de vil, samt den fælles interesse for både kolonister og koloniserede i at udvikle eksisterende produktions- og handelsformer i stedet for at ødelægge dem.

Som historikeren Kevin Grant har påvist, er det først med den fulde inddragelse af missionsbevægelsens effektive propagandaapparat - trods Morels skepsis over for "missionærbeviser" - at kampagnen opnår sit historisk set hidtil usete gennemslag. Mens Morel søgte at uddrive evangelisk retorik fra antislavebevægelsens kampagner for at understøtte bevisernes juridiske validitet, så geninstalleres denne retorik med mange gange forstærket kraft, da den protestantiske missionsbevægelse overtager den praktiske udførelse af Congo Reformkampagnen, som breder sig til det europæiske fastland og til USA. I kirker og missionshuse afholdes i tusindvis af "Congo Atrocity Meetings" ofte med et deltagerantal på flere tusinde. Og selvom missionsbevægelserne fra begyndelsen af Red Rubber-regimet ikke i nævneværdig grad var involveret i kritikken af misgerninger og først engagerede sig, da 
de nærliggende landsbyer, som selvsagt var væsentlige for missionsvirksomheden, blev affolket, blev det humanitære "korstog" en vindersag for missionsbevægelsen, der drog den største økonomiske og politiske fordel af sagen - både mht. arbejdet i Congo og mht. styrkelsen af organisationens rolle som indenrigspolitisk magtfaktor (Grant, "Christian critics of empire").

Møderne, der også blev kaldt for "lantern lectures", blev afholdt efter en gennemprøvet og virkningsfuld opskrift på grundlag af en præfabrikeret pakke, The Congo Atrocities. A Lecture to Accompany a Series of 60 Photographic Slides for the Optical Lantern, der blev distribueret internationalt. Ifølge brugsvejledningen skulle der på fastlagte tidspunkter i lysbilledforelæsningen afsynges særlige Congo-salmer og fremføres vidnesbyrd eller hvad missionærerne kaldte "horror narratives". Mødet eller "forelæsningen" havde karakter af en prædiken, men med anvendelsen af den moderne medieteknologi, som hidtil havde haft stor succes som folkeligt underholdende og chokerende Laterna Magica-fremvisninger af freaks på markedspladser, havde de en næsten massehypnotiserende virkning. Rapporter fra møderne fortæller om meget stærke emotionelle reaktioner fra publikum, der bringes i affekt, rejser sig og med råb og skrig højlydt udtrykker deres indignation eller falder i en trancelignende tilstand, indtil "forelæseren" afslutter seancen i et mere beroligende toneleje med en evangelisk bøn om håb og frelse, bl.a. via publikums politiske støtte til Congo Reformbevægelsen eller gennem pengedonationer til missionsbevægelsens arbejde i Afrika (Grant, "Christian critics of empire"; Peffer).

Det er et væsentligt element i kampagnens virkningsstrategi at udbredte fotos af især børn med afhuggede hænder og fødder, der præsenteres uden forankringer i kontekst, hvis kompleksitet under alle omstændigheder ville forstyrre den tilsigtede affekt hos betragteren. Imidlertid er billederne ofte tvetydige og foruroligende på en måde, der virker mod deres hensigt. Blandt andre har Suzanne Gehrmann argumenteret for, at fotografierne af lemlæstelserne er beskårede og iscenesatte med henblik på kampagnen og ofte præsenteres i en problematisk sammenkædning af voyeuristisk lyst og moralsk forargelse, som også degraderer de portrætterede (Gehrmann; Thompson; Twomey). Mange af fotografierne fremkalder desuden en mistanke om, at lemlæstelserne er foretaget som led i fotografiets opstilling. F.eks. er den type billeder, som fremviser afskårne hænder 
og fødder, argumentatorisk selvmodsigende. De indgår som vidnesbyrd om fristatssoldaternes berygtede praksis med at afskære hænder på døde ofre for ved fremvisning til overordnede at kunne få udleveret nye patroner. Men vidnesbyrdet modsiges og undergraves af billedets dokumentation af de løsrevne hænder, som altså tydeligvis alligevel ikke befinder sig i soldaternes varetægt og derfor rejser ubehagelige spørgsmål om, hvorfra og hvordan de så er kommet til at indgå i fotografiets opstilling.

I en behandling af fotografiets rolle i humanitære mediekampagner hæfter Sharon Sliwinski sig angående Congo Reformbevægelsen ved tre forhold: At individuelle beretninger og billeder anonymiseres og masseproduceres uden sikker forankring i tid og sted, at fremvisningerne etablerer en matrice for reproduktion af en narrativ struktur for fremførelse af vidnesbyrd, en såkaldt "standardfortælling", og som hendes væsentligste kritikpunkt, at perceptionen finder sted i en formidlingssituation, som er grundlæggende fantasmagorisk og hallucinatorisk, feberagtig. De enkelte tilfældes partikulære træk udviskes og overføres til en standardiseret og genkendelig version, bygget op omkring de stærke billeder af afhuggede hænder, hvorudfra tilskueren kan drage universelle konklusioner om andres rettigheder. Hovedproblemet er således, at det sansemæssige råmateriale for dannelsen af moderne internationale ansvars- og rettighedsmodeller formes i dette "drømmearbejde". John Peffer argumenter for en lignende stærkt problematisk sammenhæng mellem Congo Reformbevægelsen og senere menneskerettighedskampagner. Lysbilledforevisningerne frembragte en stærk følelsesmæssig respons, men i en hypnotiseret kontekst, hvis virkning beroede på glemsel og fortrængning af rædselsbilledernes kontekst, herunder udeladelse af missionærens aktive deltagelse i såvel den koloniale udnyttelse som i den iscenesættelse og genopførelse af f.eks. piskescener, som de arrangerede fotografier indebar -ægteparret Harris, der leverer flertallet af fotografierne, har f.eks. selv udført piskninger af indfødte. Med henvisning til Susan Sontags essay "Regarding the Pain of Others" anfører Peffer, at "følsomhed er fuldstændig kompatibel med smagen for brutalitet og det der er værre", samt at hver gentagelse af misgerningen i såvel missionærfotografens opstilling i Afrika som i lysbilledforevisninger i Europa er en udøvelse af vold. Anskuet performativt opbygger reformbevægelsens kampagne en forestilling om, at tilskuere gennem visuel konfrontation med 
rædselsgerninger på afstand kan ophæve virkningen af voldelige handlinger ved passivt at gennemleve en medfølelse med offeret. Når denne mekanisme samtidig forbindes med universale og transcendentale idealer om menneskelighed, værdighed og pligt, fortrænges ifølge Sliwinski samtidig enhver klar forestilling om de berørte menneskers virkelighed, hvilket føres videre som et problem i nutidens menneskerettighedsbevægelser eller i tilsvarende former for "liberal humanitarian discourse" (Sliwinski; Peffer; Thompson).

Krisen i det retoriske grundlag for menneskerettigheds- og bistandskampagner er blevet eksponeret i to provokerende kunst-dokumentarfilm, danske Mads Brüggers The Ambassador fra 2011 og hollanske Renzo Martens Episode III: Enjoy Poverty fra 2008. I begge film udnyttes barokke og burleske overdrivelser til at vende vrangen ud på de medlidenheds- og rædselsfortællinger, som driver den internationale bistandsindustri i Afrika. Dels er det tvivlsomt, om nødhjælpsorganisationerne faktisk afhjælper de lidelser, som motiverer deres tilstedeværelse, dels og mere grundlæggende, at repræsentationen af f.eks. congolesernes lidelser i vestlige medier i sidste ende medvirker til at fastholde og forstørre det ulige magtforhold. Som Martens udtaler i et interview: "Det egentlige spørgsmål er hvordan vi, modtagerne i Vesten, føler. Det er det, som afgør hvem der får hjælp og hvem der bliver bombet. Så jeg prøver på stedet at infiltrere og adoptere den vigtigste rolle i nutidens krige, nemlig mediemodtagerens rolle. Min film handler overhovedet ikke om Congo, men om de magtrelationer der er mellem dem, der betragter, og dem, der bliver betragtet." Strategien er i begge film en kynisk blotlæggelse af den udnyttelse af de indfødte, som indeholdes i de humanitære kampagners sentimentalitet. Martens siger f.eks. til en landsbybeboer, han har opfordret til at tage fotografier af sin egen elendighed for at sælge dem til vestlige medier, at han bestemt ikke har tænkt at hjælpe ham yderligere, når han er vendt tilbage til Europa: "At erfare dine lidelser gør mig til et bedre menneske. Du hjælper mig faktisk. Tak" (Herbert).

\section{GORILLABESKYTTELSESKAMPAGNER}

Stanley har i sin rejsebeskrivelse fra den Transatlantiske Afrikaekspedition flere passager, hvor han indgående drøfter mulige slægts- og udviklingsrelationer mellem chimpanser og f.eks. pygmæer målt i forhold til det euro- 
pæiske menneske som det højst stående trin og med hypoteser om gorillalignende væsner som "missing links". Sådanne refleksioner var i sidste del af 1800-tallet obligatorisk pensum i de victorianske opdagelsesrejser, som gerne skulle medbringe hovedskaller fra både aber og mennesker til antropometrisk undersøgelse i London, hvor de makabre omstændigheder omkring fremskaffelsen og konserveringen ofte tilførte ekstra brændstof til en i forvejen skandaløs mediedebat udløst af Darwins kontroversielle teser. Udover den rasende debat om, hvordan man skelner moralsk og videnskabeligt mellem dyr og menneske, var det en polemik mellem på den ene side dem, der hævdede at forskellige racer repræsenterede forskellige menneskearter, hvilket legitimerede påstanden om et nært slægtskab mellem aber og "negre", og på den anden side dem, ofte folk med rødder i antislavebevægelsen, der støttede en monogenistisk model, som satte et skel mellem aben og mennesket og dermed placerede forskellige menneskeracer på samme biologiske udviklingstrin. I kølvandet på Den Amerikanske Borgerkrig og en fornyet interesse i spørgsmålet om "negerens" biologiske væsen indbefattede den religiøse, videnskabelige, moralske og politisk-økonomiske debat alle aspekter af den offentlige diskurs (Hodgson). Derfor var interessen for "missing links", dvs. fund af nye menneskelignende arter, som kunne betyde det endegyldige bevis for det ene eller andet synspunkt, også kolossal.

I denne hyperintensive mediekontekst bliver den fransk-amerikanske eventyrer og opdagelsesrejsende Paul du Chaillus beskrivelser af gorillaen naturligvis modtaget under stor virak. Gorillaen blev første gang videnskabeligt beskrevet i 1847 af Thomas Savage, og mens der sandsynligvis var en levende gorilla med i Wombwells turnerende menageri i 1856-57, der iflg. Johannes V. Jensen senere passerede forbi de søvnige himmerlændinge i Farsø, var det først med Paul du Chaillus Explorations and Adventures in Equatorial Africa fra 1861, at gorillaen for alvor fik sin berømmelse i populærkulturen (Corniff). Tvivl om hans nationale karakter - du Chaillu var født i Île St. Réunion med en mulat som mor og en fransk far og levede den første del af sit liv i Gabon - blev sammen med hans franske manerer og mangelfulde engelsk brugt som forklaring på hans hang til at overdrive og til at så tvivl om hans historier (Lifshey). Paul du Chaillus gorillafortællinger blev hidsigt debatteret i et elektrificeret felt, hvor gorillaen på samme tid var et kostbart videnskabeligt trofæ og en metafor for upålidelighed. Den 


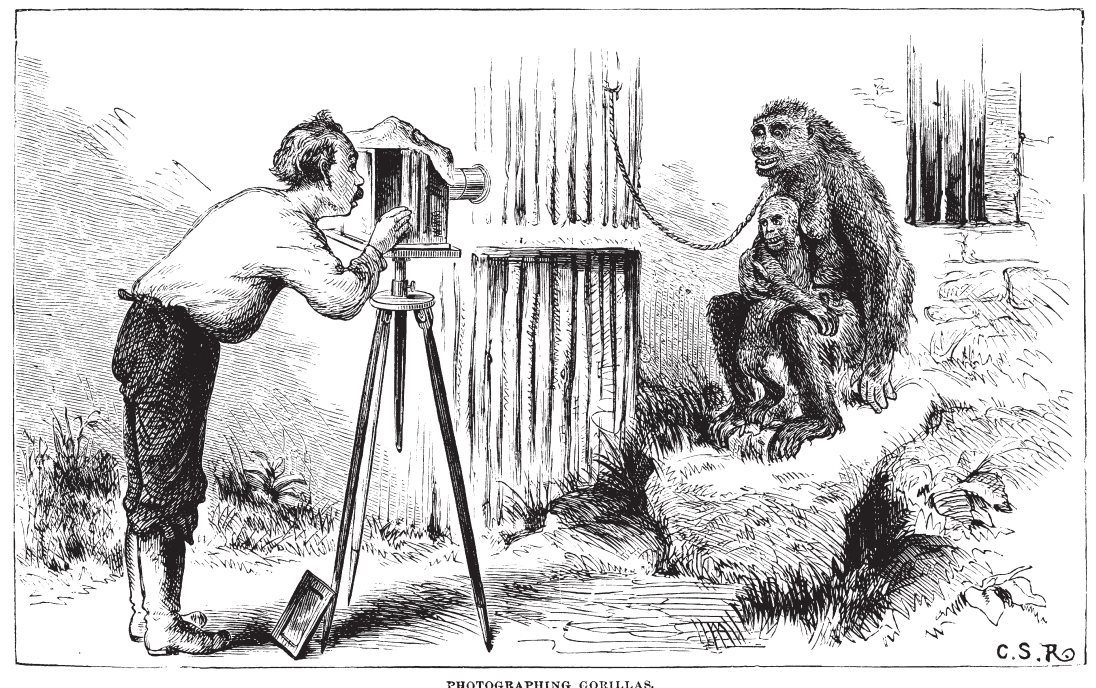

Fig. 1. Hvordan man fotograferer gorillaer.

Paul du Chaillu. The Country of the Dwarfs, 1901

populærkulturelle interesse medførte en mangfoldighed af gorilla-tekster, gorilla-pamfletter og gorilla-anmeldelser, gorilla-kvadriller, gorilla-sange og gorilla-digte, som typisk benyttede sig af det retoriske greb at lade gorillaen være "jeg" og subjekt for udsigelser af moralsk-alvorlige eller satiriske spekulationer om sin egen art, gorillaen, og om menneskearten, der nu har grebet forstyrrende ind i årtusinders fred fra civilisation (Hodgson).

Blandt andet næret af såkaldte "gorilla bortførelsesfortællinger", historier blandt både indfødte og europæere om gorillaers sabinerinderov af kvinder, der tvinges til at underkaste sig gorillaens maskuline begær, bliver gorillaen mod slutningen af det 19. århundrede til et generaliseret symbol for quasifænomener og artshybrider (Giles-Vernick og Rupp). Gorillaen repræsenterer det punkt, hvor menneskets og dyrets veje skilles, men bliver også beskrevet i genremæssige hybrider, hvor det ikke er sikkert, hvad der er fakta og hvad der er fiktion. Gorillafortællinger tilhører dermed den genre, som er kaldt for "Ecogothic", dvs. karakteriseret af troper, 
der gennemspiller grænseoverskridelser mellem genrer, arter og kroppe, spøgelsesagtige hjemsøgelser af tidligere udviklingstrin og afsøgning af positioner, der på den ene side tillader nonhumane arters ikkeantropocentriske blik på mennesket, men på den anden side skildrer denne mulighed som monstrøs og rædselsfuld - og derved i sidste ende udtrykker en "speciesism", en centristisk forestilling om artshegemoni (Miller). Modsat den populærkulturelle modtagelse af gorillaen, som i fin de siècle-kulturen også forbinder sig med den angst- og lystblandede freudianske fascination af mennesket som driftsvæsen, blandt andet i fantasier om kvinder, hvis dybeste begær kredser om at blive taget af virile hangorillaer, der også ses i den litterære dekadences behandling af "abemennesket", så forsøger du Chaillu omkring sine gorillafund at etablere en kontekst, der på samme tid er videnskabelig og populær.

Over billedteksten "Hvordan man fotograferer gorillaer" finder man i Paul du Chaillus The Country of the Dwarfs fra 1901 en illustration, som forestiller optagelsen af det første fotografi af en levende gorilla. Når det lykkes ham at tage billedet med det tunge udstyr, skyldes det, at gorillamoderen er død, og ungen klynger sig til brystet for at få mælk og omsorg. "Moderens død var smertefuld for ungen på samme måde som for et menneske", føjer du Chaillu til beskrivelsen af "det mærkværdige væsen, som Gud næsten havde skabt i menneskets billede". Fotografiet gik tabt, men tegner sig både ind i den kontekst for bevisførelse og evidens, som Mark Twain omtalte i forbindelse med Congo Reformbevægelsens brug af "the incorruptible Kodak", samtidig med at dets blodige kontekst i form af både iscenesættelse og du Chaillus bloddryppende fortællinger om gorillajagt og kannibalisme knytter an til periodens gotiske "Atrocity Meetings". Du Chaillu kunne fortælle og illustrere historien i bogen og gentage den i National Geographic Society-forelæsninger hjemme i Amerika, hvor gorillafortællinger bliver et tilløbsstykke og medvirkende til at konsolidere organisationen og det senere tidsskrift National Geographic. Senere i affæren omkring Dian Fossey bliver fotografier i National Geographic helt afgørende for at rejse penge til beskyttelse af den truede art. Primatologen Dian Fosseys beretning om en National Geographic-støttet redningsaktion over for truede bjerggorillaer i grænseområdet mellem Congo og Rwanda, Gorillas in the Mist fra 1981 og den efterfølgende filmatisering, synes desuden at gentage og omvende en 
lang række figurer fra fin de siècle-kulturens primitivisme og gotik, sådan som de manifesterer sig i både "atrocity"-kampagne og gorilla-hype, der begge kan ses som ængstelige og frydefulde reaktioner på, at en definition af mennesket som hævet over dyriske instinkter var blevet porøs.

Både som hun selv beskriver den, og sådan som den er stykket sammen af biografier, der har søgt at forklare hendes mærkelige liv og især hendes mystiske død, er historien om Dian Fossey en "go native"-fortælling, der i store træk følger Conrads fortælling om Kurtz. For at beskytte dyrene, som hun sætter højere end mennesker, er hun parat til at overskride gældende normer for civilisation og sætter dertil det sædvanlige repertoire af afstraffelser og skræmmekampagner i værk. For at undertvinge indfødte, som bebor reservatet, optræder hun som en troldmand, hvis feticher er i stand til at udføre de frygteligste forbandelser; hun foretager afbrændinger af landsbyer, kidnapper børn og udfører lynchninger og tortur. Inden for reservatets grænser virkeliggør hun dermed et koloniherredømme baseret på en blanding af totalitarisme og hekseri, som er stærkt i modstrid med både de indfødte, som beboede området, før det blev reservat, og med lokale myndigheder, som opfatter Fosseys egensindige metoder som et stort problem for de turistindtægter, der er livsnødvendige for det forarmede distrikt.

I hendes fundraising for at bevare reservatet indgår en retorik, der ligner antislavebevægelsens - med fotokampagner der via National Geographic distribueres ud i lægeklinikkernes venteværelser verden over og både udpeger gorillafamiliens habitat som en oprindelig arkadisk idyl og fortæller om overgreb og lemlæstelser. Og igen parallelt med antislavebevægelsen medfører kampagnen netop en øget efterspørgsel på gorillaerne til alverdens zoologiske haver, hvormed Dian Fossey har banet vejen for en øget indtrængning af krybskytters illegale operationer i reservatet. Med centrum i den store hangorilla med kælenavnet Digit dyrker især filmen Gorillas in the Mist: the Story of Dian Fossey med Sigourney Weaver i hovedrollen bloddryppende billeder af lemlæstede aber, der har fået skåret hænder og fødder af - hvilket griber tilbage til Congo Reformbevægelsens fremvisninger af rædselsgerninger. Den fundraising, som først fandt sted gennem organisationer som Dian Fossey Gorilla Fund International og The Digit Fund in the UK, blev senere videreført i kampagner, der fortsatte med 
at udnytte hendes verdenskendte brand, selvom de samme organisationer til sidst vendte hende ryggen, inden hun under voldsomme og uopklarede omstændigheder blev myrdet.

Hendes egen historie, de tidligste kampagner, film og biografier som f.eks. Harold Hayes The Dark Romance of Dian Fossey (1990) virker dermed sammen i en moderne mytedannelse, som viderefører væsentlige træk i motiver og retorik fra tidlige menneskerettighedskampagner. Blandt andet i National Geographic og på hjemmesiden for The Dian Fossey Gorilla Fund International kan man følge denne proces i aktuelle indsatser over for den igangværende borgerkrigs trussel mod områdets bjerggorillaer. Og en af denne retoriks effekter - $\mathrm{i} ø$ vrigt ivrigt kolporteret i globale nyhedsmedier - er, at dyrene fremstår mere menneskelige end de mennesker, som bor i området, og i højere grad kalder på humanitær indsats, mens ofrene for borgerkrigen træder i baggrunden for mediernes opmærksomhed.

Meget tyder på, at Dian Fossey i sine kampagner indledningsvist har søgt at stage traderede retoriske figurer for afsky og medfølelse, som er blevet forbundet med Congo siden Conrad, men senere er blevet fanget af sin egen fiktion eller "dark romance", nøjagtig som Kurtz. Fortællingens fascination er naturligvis forstærket af gætterierne om, hvem der myrdede Fossey, hvilket har fået nyt stof ved hjælp af vidnesbyrd, der er fremkommet i forbindelse med The International War Crimes Tribunal efter folkemordet i Rwanda.

Arven efter og betydningen af Dian Fosseys kontroversielle indsats er fortsat omstridt, både hos de gorillabeskyttelsesprogrammer og -fonde, der benytter sig af hendes navn og brand, og blandt dem, der i dag kaster et mere kritisk lys såvel på fremgangsmåden, der tydeliggør både specifikke og almene problemer i den primatologiske forskning, som på resultaterne, der ud fra videnskabelige kriterier var få og ubetydelige (Haraway). Førstnævnte hævder, at hun reddede bjerggorillaerne fra total udryddelse og medvirkede til at løfte populationen betydeligt, blandt andet ved resolut at konfrontere både krybskytter og de øvrige gorillaorganisationer, der opererede i reservatet via finansiering af indtægter fra gorillaturisme, som var skyld i mange gorillaers død på grund af overførsel af sygdomme som f.eks. influenza. Mens andre ser hende som en koloniherre, der med anvendelse af samme spektakulære medievold, som de lokale krigsherrer 
er berygtet for, med skræmmekampagner søgte at holde alle rivaler ude fra området; f.eks. er det kommet frem, at hun på sine rejser til USA indkøbte store lagre af fyrværkeri og 'magiske' halloween-rekvisitter til dette formål. I denne sammenhæng er imidlertid hendes retoriske og mediemæssige konfiguration af stedet og forholdet mellem menneske og abe interessant.

Hendes selvbiografi retoucherer næsten alle spor af forfatterens livshistorie væk, svarende til hendes udtalelse om, at hun selv ville have foretrukket at være fuldstændigt fraværende, så alene gorillaerne kunne indtage pladsen som bogens biografiske hovedpersoner. Dermed svæver hendes egen rolle og ikke kun gorillaerne "in the mist", for dermed skjules det også, at hendes aktivisme ikke kun vender sig mod de indfødte batwaer, men samtidig er en aktiv indgriben i gorillaernes miljø. Da hendes primatologi er baseret på adfærdsstudier og nærhed, indebærer den også stor risiko for overførsel af sygdomme og tilvænning til mennesker, hvilket endvidere letter krybskytternes jagt på de store dyr, befordrer turismen og øger ændringen af gorillaernes adfærd. Når de rwandiske myndigheder og rivaliserende gorillabeskyttelsesprogrammer på den ene side roste Fossey for at gøre gorillaturismen mulig og på den anden side anklagede Dian Fossey for selv at være skyld i, at hendes elskede Digit og Uncle Bert blev ofre for krybskytterne, har de derfor formentlig ret i begge dele. Digit blev fundet med afskåret hoved, og hænderne var hugget af med henblik på anvendelse som askebægre, der sælges på markedet for 10 dollars stykket. Fossey ville anvende billedet af hans lemlæstede krop på plakater med ordlyden "Kom og besøg mig i Rwanda", i film og artikler med "billeder af Digit i live og i døden til ethvert naturfredningsmagasin, jeg kan få fat i" (Mowat, 169). Hendes sløring af et forfattersubjekt i selvbiografien gør sig også gældende i den mediekampagne, som hun speedede op efter drabet på Digit, idet hun etablerede The Digit Fund og lod fotografen Ian Redmond og et BBC-hold filme det lemlæstede lig indgående, mens hendes egen intensivering af brutale forhør af og krig mod indfødte blev holdt uden for kameraernes vinkel. Som Bob Campbell fortæller i National Geographic-dokumentaren fra 2002 The Lost Film of Dian Fossey, der viser hidtil usete optagelser fra tiden i Virunga-bjergene, var det ham, der først tilskyndede Fossey til den efterligning af gorillaadfærden, som hun senere blev berømt for, for dermed at kunne komme tættere på de vilde dyr og således producere de rørende 
og ikoniske billeder af berøringer mellem gorilla og menneske. Men samtidig var det et krav fra Fosseys side, at film og fotos beregnet for National Geographics verdenspublikum ikke måtte afsløre fotografen eller kameraet.

Effekterne af disse iscenesættelser og redigeringer af billedfortællinger til det indflydelsesrige tidsskrift med global udbredelse er mange. For det første og mest åbenlyst etableres gorillaernes habitat som en undtagelse, hvor mennesket-som-gorilla og bjerggorillaen i før-syndefaldsagtig uskyld vegeterer i afskærmet afstand til civilisationen, som her er antitetisk fremstillet som helvede på jord. Uden for enklaven er både retorisk og fysisk vold nødvendige midler for at sikre grænsen mod inhumane mennesker, inden for lever mennesket posthumant eller nærmere præhumant som et fredeligt dyr side om side med antropomorfiserede gorillaer med arkaiske og forgangne tiders menneskelige dyder som ridderlighed og værdighed i behold. Vejen mellem de to verdner udgøres af en hemmelig tunnel i lighed med den passage, der i fantasy fiktioner forbinder to parallelle universer, og den bærende retoriske formel kombinerer prosopopeia, antitese og inversion med henblik på at skildre en utopisk ø i økologisk balance og uspaltet sprogløs forståelse mellem gorillaerne og den hjemvendte primatolog.

\section{VIRUNGA - FILMEN}

Virunga er instrueret af Orlando von Einsiedel og havde premiere i april 2014. Den er blevet nomineret til flere priser, heriblandt til Academy Award 2015 for Best Documentary Feature, er i samtlige anmeldelser blevet modtaget positivt og kan nu ses på Netflix. Filmholdet tog til Virunga National Park med den hensigt at dokumentere den positive udvikling inden for turismen og disse fremskridts afsmittende effekter. Allerede efter tre ugers ophold på stedet indledte oprørsgruppen M23 en offensiv mod regeringstropperne, som også truede parken og på dramatisk vis involverede parkmyndighederne, hvorefter filmens fokus skiftede fra den positive historie om fremgang - som reportager fra Afrika i dag helst skal fortælle som en reaktion på kritikken af mediernes ensidige Afrika-pessimisme - til en dækning af den komplekse konflikt. Filmen følger fire hovedpersoner: parkdirektøren Emmanuel de Merode, et medlem af den belgiske kongefamilie, som har viet sit liv til kampen for at bevare parkens naturrigdomme, 
og som i modsætning til Kong Leopold under Fristatsregimet fremstår som kompromisløs og ubestikkelig; lederen af de rangers, der patruljerer parken mod krybskytter, Rodrigue Mugaruka Katembo; gorillapasseren André Bauma og den franske journalist Mélanie Gouby, der i forvejen befinder sig i Goma og griber chancen til at lave en historie, som går et spadestik dybere i konflikten end den sædvanlige sensationsreportage om krigens rædsler.

Ligesom i Dian Fossey-filmene er der optagelser i super close-up af bjerggorillaer, der fredeligt græsser på skråningerne, og en rørende fortælling centreret omkring André Baumas omsorgsfulde pasning af syge eller efterladte gorillaunger, samt optagelser fra luften, hvor det enestående landskab med de gloende orangerøde vulkaner set fra oven og alle nuancer af grønt slår betragteren som sublim skønhed. Men André Bauma er i modsætning til Fossey omhyggelig med at skelne mellem sin gorillafamilie og sin egen menneskefamilie, og landskabet er ikke konfigureret antitetisk som i Fossey-filmenes modstilling af et "locus amoenus", en uskyldig naturtilstand hvor tiden står stille, over for et "locus horribilis", hvortil hører al civilisationens barbari. Grænsen mellem indenfor og udenfor skildres som porøs og defineret af de aktuelt herskende magtforhold på stedet og er derfor genstand for forhandling, der ikke tager hensyn til universelle dyre- eller menneskerettigheder. Og frem for alt synliggøres det i filmen, hvordan den mediemæssige iscenesættelse af konflikten samtidig er delagtig i konflikten - hvilket dels sker ved at eksplicitere filmens optagelser med skjult kamera, der, sådan som Emmanuel de Merode forklarer det, er det afgørende kampmiddel i en krig, som han og hans rangers aldrig vil kunne vinde med våben, dels ved i rulleteksterne efter filmen at udpege det politiske efterspil, som den i høj grad er part i.

I stedet for at fokusere på gorillafortællingens klassiske fordeling af lys og mørke og dens appel til medfølelse afslører filmen en langt dybere forklaringssammenhæng bag stedets økokrise: Rodrigue Katembos optagelser med skjult kamera viser, at olieselskabet SOCOs ulovlige eftersøgning i området er den udløsende faktor for M23's genoptagelse af kampene. Militsen bliver lovet en del af den forventede enorme olieindtjening mod at foranstalte bestikkelser af parkens rangers og skræmmekampagner mod både myndigheder og mod den lokale befolkning, der lever af fiskeri i Lake Edward. SOCOs plan er at få parken nedklassificeret, for, som det udtales 
af SOCOs lokale chef med kynisk og bagvendt logik: En park, hvor der bores efter olie, kan jo ikke samtidig være et UNESCO World Heritage Site. Emmanuel de Merode trues på livet, hvis han ikke opgiver modstanden, og Mélanie Goubys skjulte optagelser af samtaler med SOCOs lokale leder og hans sikkerhedschef viser et billede af en benhård organisation, der er parat til at bruge alle midler: Den lokale befolkning omtales som hjælpeløse børn, der vil være bedst tjent med, om europæerne igen overtager den fulde kontrol; det er latterligt, hvis nogle "fuckin' monkeys" skal stå i vejen for udnyttelsen af olieforekomsterne osv.

Emmanuel de Merode overlever mirakuløst efter at være blevet skudt på klos hold på vej hjem til Virunga efter at have overbragt en kritisk rapport om SOCOs aktiviteter til regeringen i Kinshasa. Rodrigue Katembo bliver tilbageholdt og tortureret, fordi han som en af de få ikke ville tage imod bestikkelse. SOCO nægter ethvert kendskab til de lyssky forretninger, men indgår alligevel under indtryk af filmens succes en aftale med World Wildlife Fund om ikke at foranstalte skadevirkninger på reservatets miljø. En aftale der som nævnt af Global Witness og Human Rights Watch betegnes som "a ruse", hvilket bekræftes få dage efter indgåelse af aftalen af SOCOs bestyrelsesformand Rui de Sousa, der erklærer "Vi har ikke trukket os ud - det er overhovedet ikke pointen", i stedet undersøges mulighederne for at få reservatets grænser tegnet om. Meddelelsen 14.3 2015 om at det netop er det, Congos regering arbejder på, viser at dette formentlig har været planen fra begyndelsen. Ifølge miljøforkæmpere vil et sådant resultat være en katastrofe ikke blot for bjerggorillaerne og for Virunga-parken, men for alle nationalparker i Afrika, hvor korrupte regeringer, i det V. S. Naipaul kaldte for "half-made societies", er parate til at lade sig købe af multinationale selskaber mod selv at få en bid af kagen. - Mens de berørte indbyggere i og omkring reservaterne kun kan se frem til endnu flere ødelæggelser af miljø og levegrundlag, selvom regeringernes aftaler om udvidelse af koncessioner sker med henvisning til, at hensynet til lokale folks fattigdom og elendighed må veje tungere end omsorgen for truede dyrearter. Som et fortilfælde henviser en artikel i New York Times til "The Selous Game Reserve", som også var et UNESCO World Heritage Site, hvis område blev kraftigt reduceret, fordi der blev fundet store forekomster af uran. -The World Heritage Commitee lod sig modstræbende overtale af Tanzanias 
regering, fordi medlemmerne ikke ville fremstå, som om de satte dyr højere end mennesker (Gettleman).

Hvad der står klart, takket være filmen Virungas afdækning af de økonomisk-politiske årsager bag både stedets økokrise og stedets humanitære krise, der forlænges og forværres på grund af SOCOs tilstedeværelse, er altså, at både dyrerettigheds- og menneskerettighedskampagner med deres rædselsfortællinger og appel om medfølelse med dyr og mennesker står magtesløse over for de kræfter, som ødelægger et sted af "enestående universel værdi" for hele menneskeheden. Chefen for SOCOs sikkerhedsstyrker i området udtrykker klart, at det eneste som gælder universelt for Afrika, er at "business is business is business".

Vurderet som diskurser har både menneskerettigheds- og dyrebeskyttelseskampagner rod i de samme retoriske grundmønstre, som i det lange stræk går tilbage til antislavebevægelsens agitation. Den forudsatte en topografisk fordeling mellem mørke, hvis vildskab evangeliet skulle fortrænge, og paradisiske lysninger, hvor indfødte sprang omkring i barnlig uskyld, for at godtgøre at missionsbevægelsens havde et fundament at bygge på og en grund til sin tilstedeværelse. Som nævnt får denne figur en særlig gotisk drejning i fin de siècle-kulturens dyrkelse af rædslen for det primitive eller nonhumane, som både "Atrocity Meetings" og den samtidige gorillafascination tog del i. Videreført i nutidige kampagner og globale massemedier som National Geographic er denne retorik performativt medvirkende til ødelæggelsen af steder som Virunga. Patetisk medfølelse med mennesker og dyr bortleder opmærksomheden fra stedets komplekse kontekst og opererer med en universalisme, som har tendens til at ekskludere de globalt betingede lokale økonomiske kriser. Især $\mathrm{Na}$ tional Geographic, som er finansieret af Gulf Oil, og WWF, der foretrækker at fremstå som en upolitisk international organisation, undgår på samme måde som tusindvis af dyreprogrammer på TV helst at adressere konkrete eksempler på ødelæggende global udnyttelse af stedets ressourcer, selvom disse medier samtidig i almene formuleringer retorisk appellerer til, at der tages økologisk hensyn til truede dyrearter. I modsætning til mere radikale dyrerettighedsaktivister, for hvem Dian Fossey kan regnes som en forgænger, som ofte opererer med en antropomorfisering af dyret og en dæmonisering af mennesket og dermed uddyber det skel mellem natur og 
kultur, som Bruno Latour blandt andre har kritiseret, ser filmen Virunga rettigheder for mennesker og dyr som sider af samme sag. Mens der på nettet som kommentarer til både Fosseys film og Virunga således fremsættes talrige xenofobe kommentarer med ønsket om, at reservatets indfødte batwaer må "brænde op i helvedet", er Virunga helt modsat et forsøg på uden medfølende retorik gennem et globalt massemedie at konfrontere betragteren med, hvad der dybest set er en kapitalismekritik: Ondets rod er i første række den koloniale plyndring af regionen, som har forhindret et land som Congo $i$ at etablere sig som en fungerende stat. Trods sin enorme udstrækning og verdenshistoriske betydning er DR Congo ikke en nation, men nærmere den natvægterstat, som Naipaul har beskrevet. Landet kan ikke påberåbe sig de mindstebestemmelser, som f.eks. Anthony Smith har opstillet for en nation: "et afgrænset fædreland", "høj autonomi" og institutionaliserede former for "historieskrivning og historisk tænkning". Og desuden er muligheden af et "forestillet fællesskab" som grundlag for en national identitet vanskeliggjort af den opdeling i og forstærkning af stammetilhørsforhold, som den belgiske koloniadministration indledte med sine antropologiske og administrative udskilninger af den indfødte befolkning i etnografiske delsystemer og stammer, og som senere blev forstærket og gjort absolutte som strategiske brikker i de politiske spil efter uafhængigheden.

I anden række er det den postkoloniale plyndring, som i jagten på diamanter og coltan og til afsætning på det globale marked har opsplittet især Kivu-distriktet i middelalderlige og stærkt voldelige hertugdømmer. SOCOs aktiviteter er blot seneste trin i denne udvikling, som vil forlænge og forstærke de voldelige konflikter, uden at den lokale befolkning får del i indtægterne, og samtidig medvirke til en truende udryddelse af de sidste gorillaer. Emmanuel de Merode og filmen Virunga er på ingen måde sentimentale, men kritiske og modige - man kunne sige "cool" - bestræbelser på at værne et enestående sted mod ødelæggelse uden at appellere til universelle menneske- eller dyrerettigheder. Filmen er ikke en standardiseret vidnesbyrdsfortælling, og dog er den rystende, fordi den overbringer en konkret sandhed om den fortsatte og hensynsløse plyndring af Afrika. Den appellerer betragteren til at handle politisk i stedet for at lade sig skræmme af den spektakulære vold, som indgår i en kalkuleret mediestrategi med det 
formål at undertrykke den lokale befolkning og - ivrigt formidlet af globale medier og rettighedskampagner - at sørge for at det internationale samfund holder sig væk fra en enklave, der dermed forekommer at være eller altid at have været fortabt og uden for det rationelles og solidaritetens felt.

Frits Andersen er lektor i Litteraturhistorie, Aarhus Universitet. Har senest udgivet doktorafhandlingen Det mørke kontinent? - Afrikabilleder i europæiske fortællinger om Congo (2010), der udvikler en litteraturhistorieskrivning på komparativt grundlag. Artiklens geokritik på baggrund af en sammenligning mellem menneskerettigheds- og gorillabeskyttelseskampagner bygger videre på denne metode. I 2015 udkommer en bog om Stillehavets fortællinger, nydelse og ø-utopier, et modstykke til Afrika-bogens behandling af dystopier og rædselsretorik.

\section{A PLACE IN AFRICA}

The Virunga National Park as a geo-critical case

The article outlines some of the historical traces for the eco-crisis that presently threatens the first and most outstanding national park in Africa, homeland of the mountain gorilla. After a short description of the site, the article presents the Congo Reform Movement's campaign against the bloody suppression in the Congo Free State around 1900, often referred to as the Red Rubber-regime. The Congo Reform Movements "Atrocity Meetings" are considered to be the first human rights campaign, because they established the rhetorical models that we find today in Amnesty International, Human Rights Watch and Global Witness. The article argues that we can detect similar and highly problematic structures in the animal rights campaigns which took on a global scale in the 1970s - initiated among others by Dian Fossey and her famous and infamous fight for the protection of mountain gorillas in the Virunga mountains. Both human rights campaigns and animal rights campaigns share a responsibility, I argue, for the eco-crisis at Virunga. Finally I present the documentary Virunga from 2014 as a model and as a rhetorical alternative.

Keywords: geocriticism, ecocriticism, human rights, animal rights, gorilla narratives, Congo Reform Movement, Dian Fossey, World Heritage 


\section{LITTERATUR}

Andersen, Frits. Det mørke kontinent. Afrikabilleder i europæiske fortællinger om Congo. Gylling: Aarhus Universitetsforlag, 2010.

Battani, Marshall. "Atrocity Aesthetics: Beyond Bodies and Compassion". Afterimage (2011). [forlag mangler]

Conniff, Richard. "Discovering Gorilla". Evolutionary Antropology 18, 2 (2009).

"Du Chaillu's Adventures in Equatorial Africa". The Edinburgh Review 1. juli 1861.

Du Chaillu, Paul. The Country of the Dwarfs. London: Harper \& Brothers, 1901.

Fossey, Dian. Gorillas in the Mist. London: Phoenix, 1981.

Geetleman, Jeffrey. "Oil Dispute Takes a Page From Congo's Bloody Past". New York Times 15. november 2014.

Gehrmann, Susanne. Congo-Greuel. Zur literarischen Konfiguration eines kolonialkritischen Diskurses (1890-1910). Hildesheim: Georg Olms Verlag, 2003.

Giles-Vernick, Tamara og Stephanie Rupp. "Visions of Apes, Reflections on Change: Telling Tales of Great Apes in Equatorial Africa". African Studies Review 49, 1 (2006).

Grant, Kevin. A Civilised Savagery. Britain and the New Slaveries in Africa, 1884-1926. London: Routledge, 2005.

Grant, Kevin. "Christian critics of empire: Missionaries, lantern lectures, and the Congo reform campaign in Britain". Journal of Imperial and Commonwealth History 29, 2 (2008).

Haraway, Donna. Primate Visions: Gender, Race, and Nature in the World of Modern Science. New York: Routledge, 1989.

Herbert, Herbert. "Renzo Martens by Martin Herbert". ArtReview (2009).

Hodgson, Amanda. "Defining the Species: apes, savages and humans on scientific and literary writing of the 1860s". Journal of Victorian Culture (2001).

Jenkins, Mark. "Who murdered the Virunga Gorillas?". National Geographic (2008).

Lifshey, Adam. "An Américain in Africa. The Transatlantic Creations of Paul Belloni du Chaillu". Journal of Transnational American Studies 3, 1 (2011).

Massey, Doreen. "En global fornemmelse for sted". Sted. Red. Anne-Marie Mai. Gylling: Aarhus Universitetsforlag, 2010.

Miller, John. "Meat, Cannibalism and Humanity in Paul du Chaillu's Explorations and Adventures in Equatorial Africa". Gothic Studies 16, 1 (2014).

Morel, Edmund D. Red Rubber. The Story of the Rubber Slave Trade Flourishing on the Congo in the Year of Grace 1906. London: T. Fisher Unwin, 1906.

Mowat, Farley. Dian Fossey og bjerggorillaerne i Afrika. København: Samleren, 1988.

Peffer, John. "Snap of the Whip/Crossroads of Shame. Flogging, Photography, and the Representation of Atrocity in the Congo Reform Campaign". Visual Anthopology Review 24 (2008).

Ringer, Greg. "Gorilla tourism". Alternatives Journal 28, 4 (2002).

Salak, Kira. "Places of Darkness". National Geographic Adventure (2004).

Salopek, Paul F. "The Mountain Gorillas of Africa. A Fragile Home Threatened by War". National Geographic 188, 4 (1995).

Sliwinski, Sharon. "The Childhood of Human Rights: The Kodak on the Congo". Journal of Visual Culture (2006). 
34 KULTUR \& KLASSE * $119 * 2015$

MELLEM EURAFRIKA OG AFROPA

Thompson, T. Jack. "Light on the dark continent: The photography of Alice Seely Harris and the Congo atrocities of the early twentieth century". International Bulletin of Missionary Research (2002).

Twomey, Christina. "Framing Atrocity: Photography and Humanitarianism". History of Photography 36, 3 (2012).

Whitlock, Gillian. "Remediating Gorilla Girl: Rape Warfare and the Limits of Humanitarian Storytelling". Biography 33, 3 (2010).

"With Mr. Gorilla's Compliments". Temple Bar 1. november 1861. 